\title{
The Federalist Debate and the Goal of Better Promoting the Federalist Idea in the World*
}

\author{
Joseph Preston Baratta
}

Book

I have nothing but praise for the new book ${ }^{1}$. The historical retrospectives, the critique of the crisis of the European Union, the exploration of other regional unions, and the enlargement of the field to world government is nimble, creative, and an addition to the literature on supranational international organization. I have read the book. I bought a copy to donate to Luis Cabrera and James Thompson, organizers of the World State Debate (www.wgresearch.org).

\section{Influence?}

My criticism is focused wholly on the influence of the book. In view of Brexit and the Trump election, which threaten almost the dissolution of seventy years of integration in the European Communities and Union, I think we must ask, Why are such thoughtful works not reaching the reading public nor busy statesmen? We seem not to have produced popular and official conviction of the principles of federalism for the building of freedom, prosperity, and peace in modern states. We can continue to speak truth to power, but do you really think the Establishment is listening?

\section{The Federalist Debate}

The journal, The Federalist Debate, seems to be on the right track. We need a scholarly journal to demand high standards for writers. This point could not be clearer on reflection that in the United States of America there is no journal that regularly gives voice to federalist thinking. Bill Pace's Institute for Policy Studies should be the publication arm of the World Federalist Movement (if it is a "movement"), but every time I search for it I find just old out-ofdate works, including some of mine from the 1980s. Even TFD is not up to date there. No movement can flourish without a journal or a newsletter. Lenin had Iskra, and Elizabeth Cady Stanton had Revolution.

\section{Editor}

I think it is time to grant Prof. Levi an award for his editorship of TFD. I suggest a beautiful plaque, in Italian, French, English, and German (?)- his languages - commemorating him for his intelligence, learning, vision, generosity, and courage. It should mention the achievements of which he is most proud (books? conferences? Acts of the Italian legislature? acts of the European Parliament?). To find out, look in his curriculum vitae. I understand that Lucio would like to retire. We must find a replacement, fluent in Italian, English, French, and perhaps German, who knows what federalism is.

Publication on Time

I do wish TFD could appear more punctually. It is always late. My recent invited editorial was written in January, published in the March issue, but did not arrive at my house in the States until May. The July issue did not arrive until October. Imagine if the Economist or the New York Review of Books was always a month or two late! 
Readership of TFD

But appearance of an article in TFD does not seem to be enough. Only once have I received a comment on one of my articles - from Keith Suter in Australia on my invited editorial in March. A vast silence, even from professed federalists, seems to greet our work. In the States, most do not appreciate the E.U.

\section{$\underline{\text { Op-Eds }}$}

I would suggest, in order to further publicize our scholarship, that the editor request every author whose work is accepted for publication in TFD to also recast the work as an opinion-editorial (op-ed) in leading newspapers. Take the New York Times or the Manchester Guardian or Le Monde diplomatique or others in Europe that you would know better. I know op-eds must be timely and have a "hook" (unusual interest). They must also offer collective solutions to vexed current problems, like threats from rogue states or domestic terrorism. I have done this three times: once on Israeli settlements in 2017, the Iran deal in 2015 and again on withdrawal from Iraq in 2007. Just to advocate federalism without rooting it in contemporary issues of foreign affairs is like saying love will conquer all.

\section{Established Journals}

Our authors should also be encouraged to prepare articles for scholarly journals that are more closely devoted to current international relations. The last time someone even remotely linked to world federalism reached such a journal was Richard Falk and Andrew Strauss in Foreign Affairs, 80 (2001), on a global parliamentary assembly. The objective is to help form ultimately influential public opinion. We must write for both the popular and the scholarly press. (I currently have an article under review at the International History Review.) I read in Current History that German philosopher Jürgen Habermas is the leading critic of the democratic deficit in the EU.

He writes that the "public sphere" does not require"one European people." Isn't that federalism? Can we encourage one or two of us to rise to the level of Habermas and widen the debate over federalism?

\section{Occasional Papers}

I think that the Center's ${ }^{2}$ occasional papers, like Lucio Levi's on a Helsinki 2 in the Mediterranean, or the Triffin paper on the Special Drawing Right, are another way to get our serious analysis and proposals into the hands of influential people.

\section{More Books}

Always, whole books, like the present one, should be encouraged, for they have a longer life and can still have an influence long after publication. I sometimes say that my goal is to change how history is written (at least that of the 1940s). The key to getting noticed by the scholarly community is a review in a leading professional journal. My book was reviewed in the Journal of American History, but I wanted one in the American Historical Review and in Choice. Nevertheless, graduate students and scholars have bumped into the book in the stacks. Paul Kennedy and Thomas G. Weiss have cited my book only to dismiss it. I wrote a book in such ordinary language and so robust against criticism that it will still be readable in 100 years.

\section{World History}

No world historian has written more fully of world government as humanity's creative response to the challenge of modern life than Arnold Toynbee. The others, such as Albert Craig, Robert Tignor, Robert Strayer, and Richard Goff whom I use in my courses, do not see any direction in world history. To my mind, they are overcome by the despair and confusion of our times. 


\section{Literature in the Field}

I sense that federalists are not very aware of the large, unworked literature in their field. I worked hard to produce scholarly, annotated bibliographies of federalism in many countries and languages in order to define the field. See Strengthening the United Nations (Greenwood, 1987), The United Nations: Meeting the World Constitutional Crisis (Clio, 1995), and The Politics of World Federation (Praeger, 2004). I have a library of rare books from the height of the movement that I would like to give away to the right scholar before I die.

\section{List of Classics of Federalism}

In an effort to inform serious people, statesmen, and scholars of the profound theory of federalism, I wonder if we might put together a short list of ten works on European federalism, like Lord Lothian's Pacifism Is Not Enough, Nor Patriotism Either, and another list of the best works of world federalism, like Grenville Clark and Louis B. Sohn's World Peace through World Law or John A. Perkins' The Prudent Peace: Law as Foreign Policy. Such a short list should be placed at the end of every issue of TFD and of every other publication. That would help to catch the eye of people who are really looking for an alternative to conventional international relations.

\section{Action Committee for the United States of}

\section{Europe}

I wonder if the Center could follow the lead of Jean Monnet's Action Committee for the United States of Europe? See his Memoirs. Monnet had the prestige and connections to invite former heads of government (like Willy Brandt) and leaders of trade unions to join in taking the initiatives that led to the Rome treaty. Are trade unions still influential? (They are down to eleven percent of labor in the U.S., compared to $20 \%$ in 1983). Perhaps in the age of globalization, one should invite CEOs of multinational corporations to cooperate. After all, MNCs, not labor unions, are now reckoned as non-state actors. The objective would be authoritative statements on next steps in integration.

\section{Fabian Society}

I have often wondered why the Fabian Society under Sidney and Beatrice Webb could form and sustain the argument for socialism in Britain for sixty years? Is European and world federalism of less consequence than English socialism? (The society was named after Quintus Fabius Maximus, Cunctator, the Roman general who avoided open battle with Hannibal but gradually wore him down by a strategy of attrition.) The Labour party victory in 1945 was the fruit of their sustained labors and that of the many others who worked in their entourage, like Harold Laski and George Bernard Shaw. Why cannot the federalists organize like this?

\section{Novels}

No novelist has written of world government since H.G. Wells' The Shape of Things to Come. Science fiction has abandoned utopia for dystopia. The exception is Star Trek, but no account is given of the formation of the Earth Federation. The episodes are of conflicts between planets, very like those between nations. Star Trek is nationalism elevated into space.

\section{Analogy of Nonviolence}

Nothing seems to have come of H.G. Wells' "open conspiracy", but we are in an open conspiracy. Perhaps the nonviolence movement, inspired by Gandhi but now not formally organized, is another example. Like nonviolence, the ideal of federation is "in the air."By knowledgeable people, it is recognized, though on a time scale of about 500 years, as was said by a respondent to Robert M. Hutchins a week after Hiroshima. 


\section{$\underline{\text { Crisis }}$}

Monnet used to say that for the hard work of uniting sovereignties, humanity will not act without a crisis. Jefferson said the same thing in a famous document: "All experience hath shewn that mankind are more disposed to suffer, while evils are sufferable, than they are to right themselves by changing the forms to which they are accustomed." We are in the midst of a massive crisis of global governance, and it will surely get worse. When the Greenland ice cap slips into the sea, or the last worker is replaced by a robot, or a nuclear exchange ends the North Korean threat, humanity will wake up and look for overdue alternatives. We should plan for that crisis.

\section{Time for Action}

Federation is a revolutionary political program. It would end the external sovereignty of states. It would elevate all Europeans into citizens of the U.S.E. and all humanity into citizens of the world. There will come a time when the ideal must be taken out of the air and made an action program. In the American Revolution, Committees of Correspondence formed in the 1760s to coordinate and organize the revolution. Today, such coordination would be done on cell phones and computers, with all the dangers of hacking and government surveillance. I personally still like old fashioned letters on paper. They focus thought, leave a record, and cannot be hacked. We should prepare for the most terrible opposition by the nationalists, who will assume their patriotic duty is to destroy us. No national revolution has been accomplished without a war, as in Germany, Italy, and the United States. Even India did not achieve its independence without the acceleration of history provided by the Second World War, which exhausted Imperial Britain. So far, no one has died in the cause of European or world federalism.

\section{Movement or Party?}

Brexit and the Trump election seem to me to have created an opportunity. Perhaps, as Karen Smith of the London School of Economics suggests in the March issue of Current History, the withdrawal of the United States from Europe, and Britain from the E.U., will function as an "external federator". Charles de Gaulle's le fédérateur. But someone has to act, like Count Cavour, who founded the newspaper Il Risorgimento in 1848 and with its support persuaded King Charles Albert to grant a liberal constitution and undertake a war with Austria, necessary for eventual Italian independence!

The Center has long opposed the creation of a federalist political party, which tends to divide people and leads to the hypocrisy of public statements in the immediate struggle for power. The division of the world is no longer between Communism and capitalism/democracy, or Left and Right. The division is between the champions of national sovereignty and the aspirants of world law. Federalists belong to the Center. Nevertheless, at the final stages of action, there may be no escaping the responsible creation of a new, federalist political party, like the Republican party in 1856, when the United States was faced with disunion over the expansion of slavery. This must be done with caution, lest we follow the example of the Communist party after 1903.

\section{Time Scale}

We might bear in mind that the English took 600 years to establish democracy - from Edward I's convening of a caucus of non- titled knights, citizens, and burgesses, which became the House of Commons, in 1295 - to David Lloyd George's Representation of the People Act (fourth reform act) in 1918. On the other hand, we must also remember that sometimes history moves with astonishing suddenness, as forces pent up for years 
finally produce revolutionary results. The dam bursts, the waters flood. The end of the Cold War was such a case. So was the Russian Revolution.

* Intervention in Turin(Italy), where the review is published, on November 7, 2017, on the occasion of the presentation of the book Federalism: A Political Theory for Our Time, edited by the local Center for Studies on Federalism and the Einstein Center for International Studies.

\section{Editor's Note}

I wish to thank Prof. Baratta on the pages of this review (I already had the opportunity to thank and discuss with him in person) for his constructive criticism, aimed at improving some practical aspects, but especially the review's capacity to be a qualified tool for making Federalism more influential in the world.

We are already working on a few more immediate improvements, and are considering other new ideas that we hope to be in a position to present to our readers and subscribers in the next issue. However, we would like to urge you to send us your own comments and ideas. Also, as a better utilization of electronic mail and websites is certainly one of the things to be considered, the readers who have not yet given us their e-mail address are invited, if they wish to be informed and/or contacted online, to do so now.

${ }^{1}$ Federalism. A Political Theory for our Time, ed. by L. Levi, G. Bordino, A.Mosconi, Brussels, Peter Lang, 2016.

${ }^{2}$ Centre for Studies on Federalism 